\title{
Serum Interleukin-6 Levels in Differential Diagnosis of Sepsis and Transient Tachypnea of Newborn
}

\author{
Yenidoğanlarda Sepsis ve Yenidoğanın Geçici Takipnesinin \\ Ayırıcı Tanısinda Serum İnterlökin-6 Düzeyleri \\ Nurdan URAS, ${ }^{1}$ Ahmet KARADA $\breve{G},{ }^{2}$ Alparslan TONBUL, ${ }^{1}$ Emin METE, ${ }^{3}$ \\ Semra KARA, ${ }^{1}$ Musemma KARABEL, ${ }^{3}$ Mustafa Mansur TATLI ${ }^{1}$ \\ ${ }^{2}$ Department of Pediatrics, Neonatology Division, Gülhane Military Medical School; \\ ${ }^{3}$ Department of Pediatrics, ${ }^{1}$ Neonatology Division, Medical Faculty of Fatih University, both in Ankara
}

Submitted / Başvuru tarihi: 28.11.2008 Accepted / Kabul tarihi: 17.03.2009

\begin{abstract}
Objectives: The aim of this study was to evaluate the role of serum interleukin-6 (IL-6) levels in the differentiation of neonatal bacterial sepsis and TTN.
\end{abstract}

Patients and Methods: The hospital records of 58 newborns with respiratory distress that were above 35 weeks of gestational age were investigated. Patients were divided into two groups. The infection group consisted of patients with proven sepsis and clinical sepsis and the remaining one was TTN group. Clinical findings and white blood cell count, serum C-reactive protein (CRP), IL-6 levels and the ratio of immature neutrophils to total neutrophils count $(I / T)$ were recorded and were compared between the two groups.

Results: Serum CRP and IL-6 levels were found higher than normal limits in both of the groups. However there was no significant difference between them. Duration of respiratory distress was longer and $\mathrm{I} / \mathrm{T}$ ratio was significantly higher in the infection group than TTN group.

Conclusion: I/T ratio and IL- 6 may contribute to the early diagnosis of sepsis with respiratory symptoms in newborn but IL-6 alone can not distinguish TTN and sepsis.

Key words: Interleukin 6; sepsis; newborn; transient tachypnea.
Amaç: Bu çalışmanın amacı yenidoğanlarda serum interlökin 6 düzeyinin bakteriyel sepsis ve yenidoğanın geçici takipnesinin ayrımında rolünün araştırılmasıdır.

Hastalar ve Yöntemler: Solunum sıkıntısı olan ve gestasyonel yaşı 35 haftadan büyük olan 58 yenidoğan çalışmaya alındı. Hastalar, kanıtlanmış veya klinik sepsisi olanlar ve yenidoğanın geçici takipnesi olanlar olmak üzere iki gruba ayrıldı. Klinik bulgular beyaz küre sayısı, C reaktif protein, serum IL-6 düzeyi, periferik yaymada immature nötrofil sayısının toplam nötrofil sayısına oranı kaydedilerek gruplar arasında karşılaş̧ırıldı.

Bulgular: Her iki grupta da serum CRP ve IL-6 düzeyleri normal limitlerden yüksek bulunmasına rağmen iki grup arasında fark yoktu. Solunum sıkıntısının süresi ve I/T oranı yenidoğanın geçici takipnesi olan grupta belirgin olarak fazla bulundu.

Sonuç: IL-6 ve I/T oranı solunum sıkıntısı olan sepsisli yenidoğanların erken tanısı konusunda katkıda bulunurken IL- 6 düzeyi tek başına yenidoğanlarda sepsis ve yenidoğanın geçici takipnesinde kullanılamaz.

Anahtar sözcükler: İnterlökin 6; sepsis; yenidoğan; yenidoğanın geçici takipnesi. 
Transient tachypnea of newborn is presented at or shortly after birth with grunting, retractions, and an increased respiratory rate. Because the symptoms of TTN are nonspecific and consistent with neonatal sepsis or pneumonia, most infants with TTN are evaluated for infection and are treated with broad-spectrum antibiotics pending a definitive diagnosis. Neonatal septicemia is a life-threatening disease. ${ }^{[1]}$ Respiratory symptoms are often the first manifestation of septicemia at this age. Such symptoms may mimic the clinical picture of transient tachypnea of the newborn. Some studies have shown that the combination of serum CRP and IL-6 are helpful in newborns evaluated for sepsis. C-reactive protein, an acute-phase reactant that increases in the presence of inflammation caused by infection or tissue injury, is synthesized in the liver. ${ }^{[2]}$ IL-6 is a pleiotropic cytokine involved in many aspects of the immune response. ${ }^{[3]}$ It is known that IL-6 is an important mediator of host response to stress and infection. ${ }^{[4,5]}$ There are some promising studies revealing IL-6 alone or in combination with CRP as good markers in the diagnosis of early onset neonatal sepsis. ${ }^{[2,3]}$ However, to our knowledge, there is no study yet for differential diagnosis of TTN and neonatal sepsis using CRP and IL-6 combination in the literature. This retrospective study aims to investigate CRP and IL-6 levels in neonates with sepsis and respiratory disorders in order to evaluate the usefulness of these parameters in distinguishing between perinatal bacterial infections and TTN in clinical practice in a newborn intensive care unit.

\section{PATIENTS AND METHODS}

The hospital records of 86 newborn infants who were admitted to our neonatal intensive care unit with respiratory distress, from January 2005 to 2006 were evaluated. All of them were above 35 weeks of gestational age. The 28 newborn infants with congenital heart disease, dysmorphic features, a history of hypoxia, and metabolic disorders were excluded.

58 patients were divided into two groups: the TTN group and the infection groups. Infection group consisted of patients with proven sepsis or diagnosis of clinical sepsis. Proven sepsis was defined as clinical suspicion of infection with a positive blood culture. Clinical sepsis was defined as a clinical suspicion of infection (at least 1 symptom from at least 3 categories), elevated serum CRP and increased immature/total neutrophils (I/T) ratio without a positive blood culture. ${ }^{[3]}$ Clinical symptoms which were used to diagnose sepsis were divided into six categories according to the previously described criteria. ${ }^{[3]}$ a) Pallor and icterus; b) lethargy, apnea, bradycardia ( $<100 / \mathrm{min})$, irritability and seizures; c) tachypnea and dyspnea; d) hypotension, tachycardia (>200/min) and compromised microcirculation; e) vomiting and abdominal distension, and f) fever and temperature instability.
The diagnosis of TTN was made according to the previously described criteria: Newborn infants at 6 to 72 hours in their life who had respiratory distress (tachypnea, dyspnea and retraction) and no clinical, X-ray and laboratory findings of sepsis and pneumonia. ${ }^{[2]}$

Gestational age, postnatal age, birth-weight, mode of delivery and duration of dyspnea of all enrolled newborn infants were recorded and compared between the two groups.

\section{Blood Samples}

Blood samples were taken from all newborn infants at onset of respiratory distress symptoms. The median sample collection time of both groups was 10th hours of life (range 7-18 hours). Blood samples were obtained to determine white blood cell counts and serum CRP, IL-6 levels. Total leukocyte counts were determined with a Sysmex XT-2000i counter (Sysmex, Kobe, Japan). Blood smear has been processed Wright's staining and total 100 leukocyte counted for each patient. Then immature neutrophils and total neutrophil ratio has been calculated. An I/T ratio of $\geq 0,20$ was used as an indicator of infection. ${ }^{[6]}$

\section{C-reactive Protein Determinations}

C-reactive protein concentration in serum was measured by rate nephelometry using Beckman Array System protein analyzer (C-reactive protein reagent set 449760; Beckman Instruments). The lower limit of detection was $4 \mathrm{mg} / \mathrm{L}$. The cutoff values for CRP were revealed as $\geq 8$ $\mathrm{mg} / \mathrm{L}(3)$.

\section{IL-6 Determinations}

IL-6 concentrations were measured by a chemiluminescence's enzyme immunometric assay (IMMULITE Automated immunoassay system; Immulite DPC, Los Angeles, CA, USA). The lower limit of IL-6 was $6 \mathrm{pg} / \mathrm{ml}$. The cutoff values for IL- 6 were revealed $\geq 20 \mathrm{pg} / \mathrm{ml}$ (3).

\section{Statistical Analysis}

All statistical analysis were performed using the SPSS program, version 11.5 (SPSS Inc, Chicago, IL, USA). All data were compared between the two groups with independent samples t-test and Mann-Whitney U test. Parameters were given as mean \pm standard deviation. A $p$ value of less than 0.05 was considered statistically significant.

\section{RESULTS}

Fifty eight newborn infants were enrolled in the study. Transient tachypnea of the newborn group consisted of 37 and the infection group consisted of 21 newborn infants. Table 1 lists descriptive data of the two groups. There was no statistically significant difference in mean gestational age, birth weight, mode of delivery and postnatal age between the groups. In the TTN group cesarean delivery $(\mathrm{C} / \mathrm{S})$ indications were as follows: fetal distress in 8 patients $(36 \%)$, non-vertex presentation in 3 patients 
Table 1. Clinical and laboratory findings of study groups

\begin{tabular}{lccc}
\hline & $\begin{array}{c}\text { Infection } \\
(\mathrm{n}=21)\end{array}$ & $\begin{array}{c}\text { TTN } \\
(\mathrm{n}=37)\end{array}$ & $p$ \\
\hline Gestational age (weeks) & $37.00 \pm 1.64$ & $37.13 \pm 1.68$ & $\mathrm{NS}$ \\
Birth weight (gr) & $2763 \pm 462$ & $2849 \pm 450$ & $\mathrm{NS}$ \\
Mode of delivery & & & \\
\hline C/S (n, \%) & $11(\% 52)$ & $22(\% 59)$ & $\mathrm{NS}$ \\
Vaginal (n, \%) & $10(\% 48)$ & $15(\% 41)$ & $\mathrm{NS}$ \\
Duration of respiratory & $140.85 \pm 61.89$ & $27.51 \pm 27.49$ & $<0.01^{*}$ \\
distress (hours) & & & \\
WBC $\left(\times 10^{3}\right)$ & $13.40 \pm 5.29$ & $15.81 \pm 5.27$ & $\mathrm{NS}$ \\
I/T ratio & $0.76 \pm 0.43$ & $0.081 \pm 0.27$ & $<0.01^{*}$ \\
CRP(mg/dL) & $26.7 \pm 2.3$ & $23.0 \pm 3.25$ & $\mathrm{NS}$ \\
IL-6 (pg/ml) & $267.5 \pm 305.3$ & $126.8 \pm 229.8$ & $\mathrm{NS}$ \\
\hline
\end{tabular}

TTN: Transient tachypnea of newborn, C/S: Caesarean section, NS: Non-significant, WBC: White blood cell, IL-6: Interleukin-6, I/T: Immature/Total rate.

* Statistically significant

(14\%), cephalopelvic disproportion in 5 patients $(23 \%)$, placenta previa in 2 patients $(9 \%)$, and oligohydramnios in 4 patients $(18 \%)$; and in the infection group: fetal distress in 4 patients $(36 \%)$, cephalopelvic disproportion in 3 patients (28\%), acute placental hemorrhage in 2 patients $(18 \%)$, and oligohydramnios in 2 patients $(18 \%)$, In infection group, 6 neonates had positive blood cultures; 4 had Coagulase Negative Staphylococci, 1 had Streptococcus viridans, and 1 had Pseudomonas spp. The remaining 15 neonates had clinical sepsis. The mothers of three newborn infants out of six had early membrane rupture, one newborn's mother had chorioamnionitis and one newborn's mother had urinary infection. The other newborn infant needed resuscitation at delivery room because of cardiorespiratory reasons. Only three of six mothers had used prenatal antibiotics.

Serum levels of CRP was higher than normal in infection and TTN groups but there was no statistically significant difference between them $(26.7 \pm 2.3 \mathrm{mg} / \mathrm{dL}$, 23.0 $\pm 3.25 \mathrm{mg} / \mathrm{dL}$, respectively, $\mathrm{p}>0.05)$.

Also serum IL-6 levels were high in both infection and TTN groups but no significant difference was observed between them $(267.5 \pm 305.3 \mathrm{mg} / \mathrm{dL}, 126.8 \pm 229.8 \mathrm{mg} / \mathrm{dL}$ respectively $\mathrm{p}>0.05$ ). We found the specificity of IL- $6 \geq 20$ range from $16 \%$ to $47 \%$ and the sensitivity range from $68 \%$ to $0.93 \%$.

We found higher $\mathrm{I} / \mathrm{T}$ ratio in infection group than TTN group $(0.76 \pm 0.43,0.081 \pm 0.27$ respectively $\mathrm{p}<0.01)$. We found the specificity of I/ T range from $34 \%$ to $67 \%$ and the sensitivity range from $57 \%$ to $93 \%$. Combination of IL-6 and I/T ratio yielded a sensitivity of $80 \%$, a specificity of $48 \%$, a positive predictive value of $44.7 \%$, and a negative predictive value of $80 \%$. The duration of dyspnea was also longer in infection group than TTN group (140.85 \pm 61.89 hours, $27.51 \pm 27.49$ hours respectively $\mathrm{p}<0.01)$.

\section{DISCUSSION}

This retrospective study has shown that IL-6 concentration at onset of symptoms may not distinguish between TTN and proven sepsis and clinical sepsis. Nor might initial CRP levels exclude newborn infants with TTN. These results are not in concordance with findings reported in clinical studies. ${ }^{[2,3]}$ This may be explained by the alteration of the diagnostic value of IL-6 at birth by the physiologic severity and risk indexes. IL-6 mediates a nonspecific inflammatory response in tissue injuries and infections, catecholamines and epinephrine in particular have been shown to increase IL-6 production. ${ }^{[5,7,8]}$ IL-6 may not be a good parameter for excluding the possibility of sepsis and thereby eliminating the need for antibiotics. The sensitivity of IL-6 in initial determinations for the diagnosis of early onset neonatal sepsis has been reported to be consistently increased in newborn infants, with specificities ranging from 0.88 to $0.93{ }^{[4]}$ However in our study the IL-6 specifity had been found lower than previously reported studies.

C-reactive protein alone is of limited value at onset of symptoms. Although CRP is highly sensitive, it had a relatively low sensitivity on day $0 .{ }^{[9]}$ Previous studies have sought to identify which pre and perinatal complications would mimic or mask alterations in the CRP response caused by infection but have yielded conflicting results. ${ }^{[10]}$ Some maternal factors such as premature rupture of membranes (PROM), perinatal asphyxia, and other problems not resulting from infection are associated with increased CRP. ${ }^{[1,12]}$ In a neonatal intensive care unit (NICU) population with wide ranging differences in age, CRP was increased in those with a history of PROM, fetal distress, and chorioamnionitis. ${ }^{[11-13]}$

The maximum CRP response occurs around 24 hours after onset (day 1). C-reactive protein should therefore be used mainly in serial determinations. In our study CRP was unable to distinguish TTN and infection groups. Although all of the patients were admitted to the NICU on the first day of their life, serial measurements of inflammatory markers were not performed. Also ten patients in the TTN group $(27 \%)$ had fetal distress that may have influenced the results of CRP.

The high I/T ratio is a well known and simple method to predict infection in newborn. ${ }^{[14]}$ In this study we found higher I/T ratios in newborn infants with sepsis than with TTN. I/T ratio is a very simple, and a bedside method when compared to measurement of IL-6. Ang et al. ${ }^{[15]}$ have reported that the specificity of $\mathrm{I} / \mathrm{T}$ range from $75 \%$ to $91 \%$ and the sensitivity range from $22 \%$ to $47 \%$. These studies demonstrate that $\mathrm{I} / \mathrm{T}$ ratio is less sensitive but more specific in the diagnosis of neonatal sepsis. This emphasizes use of multiple indicators for detection of sepsis. In our study I/ T ratio had been consistent with previously published studies. 
The duration of respiratory distress was found longer in newborns with sepsis in this study. This is not a surprising finding because of the natural course of TTN. But these clinical findings are meaningful 3 days after birth. Therefore it can not preclude overdiagnosis of sepsis and unnecessary use of antibiotics.

All measurements in this study were done on day 1 of life. The absence of serial measurements of serum IL-6 and CRP levels is a limitation of this study. A prospective study that includes serial IL-6 and CRP level measurements can give more precise results.

In conclusion this study showed that IL-6 can not distinguish between sepsis and TTN in newborn infants. We suggest that IL-6 should be used in combination with other clinical and laboratory findings in the early diagnosis of neonatal sepsis.

\section{REFERENCES}

1. Eicher DJ, Annibale DJ. Neonatal sepsis: evaluation and management. J S C Med Assoc 2002;98:106-12.

2. Källman J, Ekholm L, Eriksson M, Malmström B, Schollin J. Contribution of interleukin- 6 in distinguishing between mild respiratory disease and neonatal sepsis in the newborn infant. Acta Paediatr 1999;88:880-4.

3. Doellner H, Arntzen KJ, Haereid PE, Aag S, Austgulen R. Interleukin-6 concentrations in neonates evaluated for sepsis. J Pediatr 1998;132:295-9.

4. Chiesa C, Pellegrini G, Panero A, Osborn JF, Signore F, Assumma M, et al. C-reactive protein, interleukin-6, and procalcitonin in the immediate postnatal period: influence of illness severity, risk status, antenatal and perinatal complications, and infection. Clin Chem 2003;49:60-8.

5. Miller LC, Isa S, LoPreste G, Schaller JG, Dinarello CA.
Neonatal interleukin-1 beta, interleukin-6, and tumor necrosis factor: cord blood levels and cellular production. J Pediatr 1990;117:961-5.

6. Philip AG, Hewitt JR. Early diagnosis of neonatal sepsis. Pediatrics 1980;65:1036-41.

7. Liao J, Keiser JA, Scales WE, Kunkel SL, Kluger MJ. Role of epinephrine in TNF and IL-6 production from isolated perfused rat liver. Am J Physiol 1995;268:R896-901.

8. Takaki A, Huang $\mathrm{QH}$, Somogyvári-Vigh A, Arimura A. Immobilization stress may increase plasma interleukin-6 via central and peripheral catecholamines. Neuroimmunomodulation 1994;1:335-42.

9. Ng PC, Cheng SH, Chui KM, Fok TF, Wong MY, Wong W, et al. Diagnosis of late onset neonatal sepsis with cytokines, adhesion molecule, and C-reactive protein in preterm very low birthweight infants. Arch Dis Child Fetal Neonatal Ed 1997;77:F221-7.

10. Jaye DL, Waites KB. Clinical applications of C-reactive protein in pediatrics. Pediatr Infect Dis J 1997;16:735-46.

11. Shim SS, Romero R, Jun JK, Moon KC, Kim G, Yoon BH. $\mathrm{C}$-reactive protein concentration in vaginal fluid as a marker for intra-amniotic inflammation/infection in preterm premature rupture of membranes. J Matern Fetal Neonatal Med 2005;18:417-22.

12. Xanthou M, Fotopoulos S, Mouchtouri A, Lipsou N, Zika I, Sarafidou J. Inflammatory mediators in perinatal asphyxia and infection. Acta Paediatr Suppl 2002;91:92-7.

13. Ainbender E, Cabatu EE, Guzman DM, Sweet AY. Serum C-reactive protein and problems of newborn infants. J Pediatr 1982;101:438-40.

14. Gonzalez BE, Mercado CK, Johnson L, Brodsky NL, Bhandari V. Early markers of late-onset sepsis in premature neonates: clinical, hematological and cytokine profile. J Perinat Med 2003;31:60-8.

15. Ang AT, Ho NK, Chia SE. The usefulness of CRP and I/T ratio in early diagnosis of infections in Asian newborns. J Singapore Paediatr Soc 1990;32:159-63. 